\title{
Planned Activity Repeat Frequency Code
}

National Cancer Institute

\section{Source}

National Cancer Institute. Planned Activity Repeat Frequency Code. NCI Thesaurus. Code C94001.

A coded value specifying the number of occurrences of a planned activity within a given time period. 